ISSN: 1858-4837; E-ISSN: 2598-019X

Volume 15, Nomor 1 (2020), https://jurnal.uns.ac.id/region

DOI: 10.20961/region.v15i1.24136

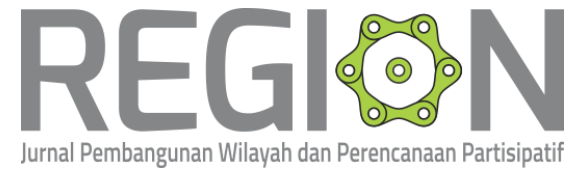

\title{
Kajian infrastruktur dalam mendukung kegiatan industri lurik ATBM (Studi kasus: Desa Tlingsing, Klaten)
}

\author{
Study of infrastructure to support handloom striated industrial estate (Case study: \\ Tlingsing Village, Klaten)
}

\author{
D I Saputro ${ }^{1}$, G Yudana ${ }^{1}$, dan I Aliyah ${ }^{1}$ \\ ${ }^{1}$ Program Studi Prencanaan Wilayah dan Kota, Fakultas Teknik, Universitas Sebelas \\ Maret
}

Corresponding author's email: dimasindosaputro@gmail.com

\begin{abstract}
Abstrak. Ketersediaan infrastruktur merupakan faktor penting dalam kelancaran kegiatan di kawasan industri lurik. Salah satu kawasan industri lurik ATBM terbesar yakni di Desa Tlingsing, Kecamatan Cawas, Kabupaten Klaten. Desa Tlingsing dalam pengembangan kawasan industri lurik Alat Tenun Bukan Mesin (ATBM) memiliki kendala dalam ketersediaan infrastruktur. Penelitian ini bertujuan untuk mengetahui ketersediaan infrastruktur dalam memenuhi kebutuhan kawasan industri lurik. Metode yang digunakan dalam penelitian ini yaitu analisis skoring guna mengetahui ketersediaan infrastruktur dalam memenuhi kebutuhan kawasan industri lurik ATBM. Hasil penelitian menunjukkan bahwa seluruh infrastruktur yang tersedia sudah mampu memenuhi kebutuhan sebagai kawasan industri lurik, terkecuali jaringan pengolah limbah dan drainase.
\end{abstract}

Kata Kunci: ATBM; Industri Lurik; Infrastruktur; Kawasan Industri; Skoring

\begin{abstract}
The availability of infrastructure is an important factor for activities continuity in the handloom striated industrial area. One of the largest handloom striated industrial estate is in Tlingsing Village, Cawas District, Klaten Regency. Tlingsing Village has constraints in the availability of infrastructure in developing the handloom striated industrial area. This research aims is knowing the availability of the infrastructure to fulfill the needs of the handloom striated industrial area. The method used in this study is the scoring analysis technique for finding out the availability of the infrastructure to
\end{abstract}

Received : September 21, 2018; Accepted: October 10, 2018; Available online: January 10, 2020

Copyright ( 2020, REGION: Jurnal Pembangunan Wilayah dan Perencanaan Partisipatif 
fulfill the needs of the handloom striated industrial area. The result shows that all available infrastructure is able to meet the needs as a striated industrial area, except for sewage and drainage processing networks.

Keywords: Handloom; Industrial Area; Infrastructure; Scooring Technique; Striated

\section{Pendahuluan}

Kawasan industri merupakan pemusatan kelompok kegiatan industri yang mementingkan kegiatan produksi, kegiatan pemasaran atau hubungan timbal balik serta dilengkapi dengan sarana dan prasarana penunjang kegiatan industri [1-3]. Berdasarkan ukurannya, terdapat kawasan industri kecil yang terdiri atas industri-industri dengan skala kecil baik produksi, modal dan tenaga kerja serta teknologi yang sederhana [4]. Salah satu bentuk industri kecil adalah industri rumah tangga yang pekerjanya merupakan anggota keluarga, menjalankan proses produksi manual, produksi bersifat musiman dan jenis produksi sederhana untuk konsumsi sederhana.

Kabupaten Klaten merupakan salah satu kabupaten di provinsi Jawa Tengah yang memiliki beberapa potensi industri kecil diantaranya sentra industri konveksi, karung goni, gerabah, lurik ATM/ATBM, kerajinan wayang dan payung kertas (Badan Pusat Statistik Kabupaten Klaten, 2014) [5]. Menurut data kelompok industri di Kabupaten Klaten diketahui bahwa industri tenun baik ATM (alat tenun mesin) maupun ATBM (alat tenun bukan mesin/tradisional) memiliki sentra industri sebanyak 26 dan 1078 unit usaha yang tersebar di seluruh Kabupaten Klaten [6]. Jumlah tersebut tergolong besar dibandingkan dengan potensi industri yang lain di Kabupaten Klaten. Dari data tersebut dapat dikatakan bahwa industri lurik ATBM layak untuk dikembangkan.

Infrastruktur merupakan fasilitas fisik yang dikembangkan dan dibutuhkan guna mendukung fungsi pemerintahan dalam penyediaan air, pengolahan limbah, tenaga listrik dan pelayanan lain dalam upaya mencapai tujuan sosial dan ekonomi [7]. Kawasan industri secara umum memerlukan prasarana pergerakan barang dan manusia, jaringan air bersih, penyuplai energi, jaringan pengolah limbah, jaringan drainase, jaringan air kotor, jaringan telekomunikasi serta fasilitas sosial dan fasilitas umum [3, 8-9]. Dalam hal ini, infrastruktur tersebut diperlukan guna memenuhi kebutuhan untuk kegiatan industri lurik ATBM yakni kegiatan produksi dan kegiatan pemasaran.

Kawasan industri lurik ATBM Desa Tlingsing menggunakan sumber air bersih berasal dari sumur tanah namun, kondisi air yang mengandung kapur membuat air tersebut hanya dapat digunakan untuk MCK. Akses menuju Desa Tlingsing cukup sulit karena kondisi jalan yang kurang baik Kondisi drainase yang buruk dan talud yang rusak memicu terjadinya banjir di Desa Tlingsing. Selain itu, di Desa Tlingsing tidak tersedia bangunan pengolah limbah. 
Bertolak dari permasalahan terkait infrastrukur di sentra industri lurik ATBM Desa Tlingsing diatas, maka muncul pertanyaan penelitian berupa bagaimanakah ketersediaan infrastruktur dalam memenuhi kebutuhan untuk kegiatan di kawasan industri lurik ATBM saat ini. Tujuan dari penelitian ini adalah mengetahui ketersediaan infrastruktur dalam memenuhi kebutuhan kawasan industri lurik ATBM Desa Tlingsing. Hal ini membedakan penelitian ini dengan penelitian-penelitan yang sudah ada sebelumnya, dimana penelitian sebelumnya hanya membahas tentang dampak dari kegiatan industri lurik terhadap perekonomian di Desa Tlingsing.

\section{Metode}

Pada penelitian ini digunakan pendekatan deduktif dengan jenis penelitian kuantitatif. Proses pengumpulan data dilakukan dengan survey primer yakni observasi pada setiap jaringan infrastruktur di Desa Tlingsing dan pengisian kuisioner oleh pengrajin lurik serta pengelola showroom di Desa Tlingsing. Sampel pada penelitian ini yakni 88. Tolok ukur variabel penelitian dapat dilihat pada Tabel 1.

Tabel 1. Tolok ukur variabel penelitian [3, 8-10].

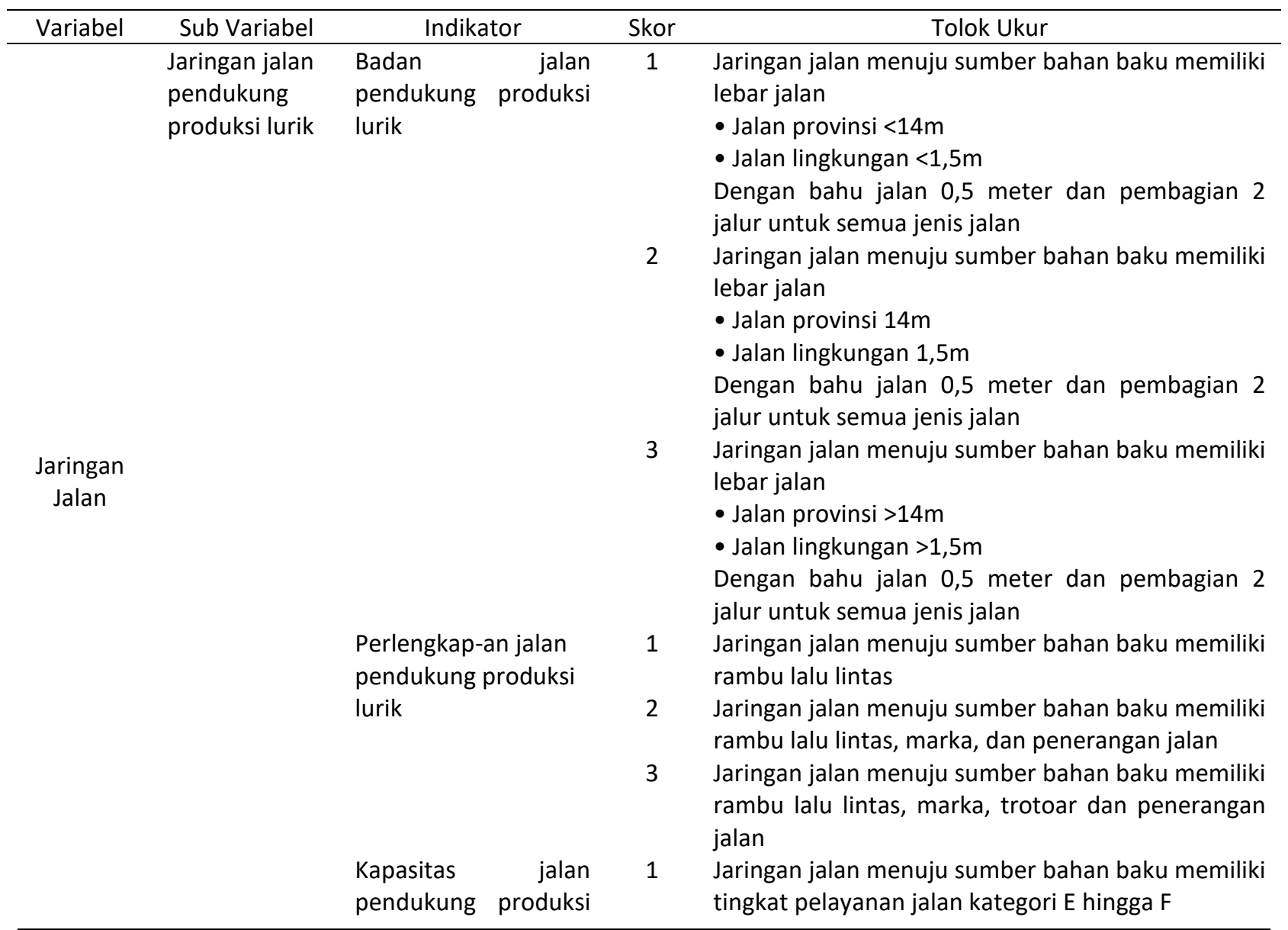




\begin{tabular}{|c|c|c|c|c|}
\hline Variabel & Sub Variabel & Indikator & Skor & Tolok Ukur \\
\hline & & lurik & 2 & $\begin{array}{l}\text { Jaringan jalan menuju sumber bahan baku memiliki } \\
\text { tingkat pelayanan jalan kategori } C \text { hingga } D\end{array}$ \\
\hline & & & 3 & $\begin{array}{l}\text { Jaringan jalan menuju sumber bahan baku memiliki } \\
\text { tingkat pelayanan jalan kategori } A \text { hingga } B\end{array}$ \\
\hline & $\begin{array}{l}\text { Jaringan jalan } \\
\text { pendukung } \\
\text { pemasaran } \\
\text { lurik }\end{array}$ & $\begin{array}{l}\text { Badan jalan } \\
\text { pendukung } \\
\text { pemasaran lurik }\end{array}$ & 1 & $\begin{array}{l}\text { Jaringan jalan menuju lokasi transit terdekat } \\
\text { memiliki lebar jalan } \\
\text { - Jalan provinsi }<14 \mathrm{~m} \\
\text { - Jalan lingkungan }<1,5 \mathrm{~m} \\
\text { Dengan bahu jalan } 0,5 \text { meter dan pembagian } 2 \\
\text { jalur untuk semua jenis jalan }\end{array}$ \\
\hline & & & 2 & $\begin{array}{l}\text { Jaringan jalan menuju lokasi transit terdekat } \\
\text { memiliki lebar jalan } \\
\text { - Jalan provinsi } 14 \mathrm{~m} \\
\text { - Jalan lingkungan } 1,5 \mathrm{~m} \\
\text { Dengan bahu jalan } 0,5 \text { meter dan pembagian } 2 \\
\text { jalur untuk semua jenis jalan }\end{array}$ \\
\hline & & & 3 & $\begin{array}{l}\text { Jaringan jalan menuju lokasi transit terdekat } \\
\text { memiliki lebar jalan } \\
\text { - Jalan provinsi }>14 \mathrm{~m} \\
\text { - Jalan lingkungan }>1,5 \mathrm{~m} \\
\text { Dengan bahu jalan } 0,5 \text { meter dan pembagian } 2 \\
\text { jalur untuk semua jenis jalan }\end{array}$ \\
\hline & & $\begin{array}{l}\text { Perlengkap-an jalan } \\
\text { pendukung }\end{array}$ & 1 & $\begin{array}{l}\text { Jaringan jalan menuju lokasi transit terdekat } \\
\text { memiliki rambu lalu lintas }\end{array}$ \\
\hline & & pemasaran lurik & 2 & $\begin{array}{l}\text { Jaringan jalan menuju lokasi transit terdekat } \\
\text { memiliki rambu lalu lintas, marka, dan penerangan } \\
\text { jalan }\end{array}$ \\
\hline \multirow[t]{5}{*}{$\begin{array}{l}\text { Jaringan } \\
\text { Jalan }\end{array}$} & \multirow{4}{*}{$\begin{array}{l}\text { Jaringan jalan } \\
\text { pendukung } \\
\text { pemasaran } \\
\text { lurik }\end{array}$} & $\begin{array}{l}\text { Perlengkapan jalan } \\
\text { pendukung } \\
\text { pemasaran lurik }\end{array}$ & 3 & $\begin{array}{l}\text { Jaringan jalan menuju lokasi transit terdekat } \\
\text { memiliki rambu lalu lintas, marka, trotoar dan } \\
\text { penerangan jalan }\end{array}$ \\
\hline & & $\begin{array}{l}\text { Kapasitas jalan } \\
\text { pendukung } \\
\text { pemasaran lurik }\end{array}$ & 1 & $\begin{array}{l}\text { Jaringan jalan menuju lokasi transit terdekat } \\
\text { memiliki tingkat pelayanan jalan kategori } \mathrm{E} \text { hingga } \\
\mathrm{F}\end{array}$ \\
\hline & & & 2 & $\begin{array}{l}\text { Jaringan jalan menuju lokasi transit terdekat } \\
\text { memiliki tingkat pelayanan jalan kategori } \mathrm{C} \text { hingga } \\
\mathrm{D}\end{array}$ \\
\hline & & & 3 & $\begin{array}{l}\text { Jaringan jalan menuju lokasi transit terdekat } \\
\text { memiliki tingkat pelayanan jalan kategori A hingga } \\
\text { B }\end{array}$ \\
\hline & $\begin{array}{l}\text { Jaringan air } \\
\text { bersih } \\
\text { pendukung }\end{array}$ & $\begin{array}{l}\text { Penyediaan jaringan } \\
\text { air bersih pendukung } \\
\text { produksi lurik }\end{array}$ & 1 & $\begin{array}{l}\text { Seluruh pelaku industri tidak terjangkau pelayanan } \\
\text { Pamsimas dan PDAM tetapi air bersih diperoleh } \\
\text { dari sumur tanah }\end{array}$ \\
\hline \multirow[t]{2}{*}{$\begin{array}{l}\text { Jaringan } \\
\text { air bersih }\end{array}$} & produksi lurik & & 2 & $\begin{array}{l}\text { Pelaku industri lurik terjangkau pelayanan air } \\
\text { bersih PDAM atau Pamsimas dan sumur tanah } \\
\text { namun tidak tersedia keran umum maupun hidran }\end{array}$ \\
\hline & & & 3 & $\begin{array}{l}\text { Pelaku industri lurik terjangkau pelayanan air } \\
\text { bersih PDAM atau Pamsimas dan sumur tanah } \\
\text { serta tersedia kran umum setiap } 100 \text { meter dan }\end{array}$ \\
\hline
\end{tabular}

Received : September 21, 2018; Accepted: October 10, 2018; Available online: January 10, 2020 33

Copyright $\odot$ 2020, REGION: Jurnal Pembangunan Wilayah dan Perencanaan Partisipatif 


\begin{tabular}{|c|c|c|c|c|}
\hline Variabel & Sub Variabel & Indikator & Skor & Tolok Ukur \\
\hline & \multirow{13}{*}{$\begin{array}{l}\text { Jaringan air } \\
\text { bersih } \\
\text { pendukung } \\
\text { pemasaran } \\
\text { lurik }\end{array}$} & & & hidran setiap 200 meter \\
\hline & & $\begin{array}{l}\text { Ketersediaan air } \\
\text { bersih produksi lurik }\end{array}$ & 1 & $\begin{array}{l}\text { Debit air } 0,05-0,15 \text { liter/detik/ha dengan kualitas } \\
\text { air yang berbau, berwarna dan keruh serta } \\
\text { mengalir terus selama } 7 \times 24 \text { jam dengan debit } \\
\text { tidak stabil }\end{array}$ \\
\hline & & \multirow{5}{*}{$\begin{array}{l}\text { Kebutuhan air bersih } \\
\text { produksi lurik }\end{array}$} & 2 & $\begin{array}{l}\text { Debit air } 0,15-0,25 \text { liter/detik/ha dengan kualitas } \\
\text { air tidak berbau, tidak berasa, jernih dan tidak } \\
\text { berwarna. Selain itu, mengalir terus selama } 7 \times 24 \\
\text { jam dengan debit tidak stabil }\end{array}$ \\
\hline & & & 3 & $\begin{array}{l}\text { Debit air lebih dari } 0,25 \text { liter/detik/ha dengan } \\
\text { kualitas air tidak berbau, tidak berasa, jernih dan } \\
\text { tidak berwarna. Selain itu, mengalir terus selama } 7 \\
\text { x } 24 \text { jam dengan debit stabil }\end{array}$ \\
\hline & & & 1 & $\begin{array}{l}\text { Kuantitas air bersih kawasan industri lurik < } \\
\text { kebutuhan air bersih standar industri kecil dan } \\
\text { kuantitas air minum kawasan industri lurik < } \\
\text { kuantitas air minum pengrajin lurik }\end{array}$ \\
\hline & & & 2 & $\begin{array}{l}\text { Kuantitas air bersih kawasan industri lurik = } \\
\text { kebutuhan air bersih standar industri kecil dan } \\
\text { kuantitas air minum kawasan industri lurik = } \\
\text { kuantitas air minum pengrajin lurik }\end{array}$ \\
\hline & & & 3 & $\begin{array}{l}\text { Kuantitas air bersih kawasan industri lurik > } \\
\text { kebutuhan air bersih standar industri kecil dan } \\
\text { kuantitas air minum kawasan industri lurik > } \\
\text { kuantitas air minum pengrajin lurik }\end{array}$ \\
\hline & & \multirow[t]{3}{*}{$\begin{array}{l}\text { Penyediaan jaringan } \\
\text { air bersih pendukung } \\
\text { pemasaran lurik }\end{array}$} & 1 & $\begin{array}{l}\text { Seluruh showroom dan pengunjung tidak } \\
\text { terjangkau pelayanan Pamsimas dan PDAM tetapi } \\
\text { menggunakan air dari sumur tanah }\end{array}$ \\
\hline & & & 2 & $\begin{array}{l}\text { Seluruh showroom dan pengunjung terjangkau } \\
\text { pelayanan air bersih PDAM atau Pamsimas dan } \\
\text { sumur tanah namun tidak tersedia keran umum } \\
\text { maupun hidran }\end{array}$ \\
\hline & & & 3 & $\begin{array}{l}\text { Seluruh showroom dan pengunjung terjangkau } \\
\text { pelayanan air bersih PDAM atau Pamsimas dan } \\
\text { sumur tanah serta tersedia kran umum setiap } 100 \\
\text { meter dan hidran setiap } 200 \text { meter }\end{array}$ \\
\hline & & \multirow[t]{3}{*}{$\begin{array}{l}\text { Ketersediaan air } \\
\text { bersih pemasaran } \\
\text { lurik }\end{array}$} & 1 & $\begin{array}{l}\text { Debit air } 0,05-0,15 \text { liter/detik/ha dengan kualitas } \\
\text { air yang berbau, berwarna dan keruh serta } \\
\text { mengalir terus selama } 7 \times 24 \text { jam dengan debit } \\
\text { tidak stabil }\end{array}$ \\
\hline & & & 2 & $\begin{array}{l}\text { Debit air } 0,15-0,25 \text { liter/detik/ha dengan kualitas } \\
\text { air tidak berbau, tidak berasa, jernih dan tidak } \\
\text { berwarna. Selain itu, mengalir terus selama } 7 \times 24 \\
\text { jam dengan debit tidak stabil }\end{array}$ \\
\hline & & & 3 & $\begin{array}{l}\text { Debit air lebih dari } 0,25 \text { liter/detik/ha dengan } \\
\text { kualitas air tidak berbau, tidak berasa, jernih dan } \\
\text { tidak berwarna. Selain itu, mengalir terus selama } 7 \\
\text { x } 24 \text { jam dengan debit stabil }\end{array}$ \\
\hline
\end{tabular}

Received : September 21, 2018; Accepted: October 10, 2018; Available online: January 10, 2020 


\begin{tabular}{|c|c|c|c|c|}
\hline Variabel & Sub Variabel & Indikator & Skor & Tolok Ukur \\
\hline & & $\begin{array}{l}\text { Kebutuhan air bersih } \\
\text { pemasaran lurik }\end{array}$ & 1 & $\begin{array}{l}\text { Kuantitas air bersih kawasan industri lurik = } \\
\text { kebutuhan air bersih showroom dan pengunjung } \\
\text { dan kuantitas air minum kawasan industri lurik } \\
\text { kuantitas air minum showroom dan pengunjung }\end{array}$ \\
\hline \multirow[t]{10}{*}{$\begin{array}{l}\text { Jaringan } \\
\text { air bersih }\end{array}$} & $\begin{array}{l}\text { Jaringan air } \\
\text { bersih } \\
\text { pendukung } \\
\text { pemasaran }\end{array}$ & $\begin{array}{l}\text { Kebutuhan air bersih } \\
\text { pemasaran lurik }\end{array}$ & 2 & $\begin{array}{l}\text { Kuantitas air bersih kawasan industri lurik = } \\
\text { kebutuhan air bersih showroom dan pengunjung } \\
\text { dan kuantitas air minum kawasan industri lurik } \\
\text { kuantitas air minum showroom dan pengunjung }\end{array}$ \\
\hline & lurik & & 3 & $\begin{array}{l}\text { Kuantitas air bersih kawasan industri lurik > } \\
\text { kebutuhan air bersih showroom dan pengunjung } \\
\text { dan kuantitas air minum kawasan industri lurik > } \\
\text { kuantitas air minum showroom dan pengunjung }\end{array}$ \\
\hline & Jaringan listrik & Penyediaan daya & 1 & Pengrajin lurik tidak tersedia sambungan listrik \\
\hline & $\begin{array}{l}\text { pendukung } \\
\text { produksi lurik }\end{array}$ & $\begin{array}{l}\text { listrik pendukung } \\
\text { produksi lurik }\end{array}$ & 2 & $\begin{array}{l}\text { Pengrajin lurik tersedia sambungan listrik secara } \\
\text { langsung dengan daya } 450 \mathrm{VA}\end{array}$ \\
\hline & & & 3 & $\begin{array}{l}\text { Pengrajin lurik tersedia sambungan listrik secara } \\
\text { langsung dengan daya } 900 \mathrm{VA}\end{array}$ \\
\hline & & $\begin{array}{l}\text { Penyediaan } \text { jaringan } \\
\text { listrik pendukung }\end{array}$ & 1 & $\begin{array}{l}\text { Tersedia jaringan distribusi sekunder dan tidak } \\
\text { tersedia penerangan }\end{array}$ \\
\hline & & produksi lurik & 2 & $\begin{array}{l}\text { Tersedia jaringan distribusi primer dan sekunder } \\
\text { serta penerangan }\end{array}$ \\
\hline & & & 3 & $\begin{array}{l}\text { Tersedia jaringan transmisi, distribusi primer dan } \\
\text { sekunder serta penerangan }\end{array}$ \\
\hline & & $\begin{array}{l}\text { Kebutuhan } \\
\text { produksi lurik }\end{array}$ & 1 & $\begin{array}{l}\text { Ketersediaan listrik kawasan industri }<\text { kebutuhan } \\
\text { listrik produksi lurik dan ketersediaan listrik } \\
\text { kawasan industri }<\text { kebutuhan listrik pengrajin lurik }\end{array}$ \\
\hline & & & 2 & $\begin{array}{l}\text { Ketersediaan listrik kawasan industri = kebutuhan } \\
\text { listrik produksi lurik dan ketersediaan listrik } \\
\text { kawasan industri = kebutuhan listrik pengrajin lurik }\end{array}$ \\
\hline \multirow{9}{*}{$\begin{array}{l}\text { Jaringan } \\
\text { listrik }\end{array}$} & & & 3 & $\begin{array}{l}\text { Ketersediaan listrik kawasan industri }>\text { kebutuhan } \\
\text { listrik produksi lurik dan ketersediaan listrik } \\
\text { kawasan industri > kebutuhan listrik pengrajin lurik }\end{array}$ \\
\hline & Jaringan listrik & Penyediaan daya & 1 & Showroom tidak tersedia sambungan listrik \\
\hline & $\begin{array}{l}\text { pendukung } \\
\text { pemasaran }\end{array}$ & $\begin{array}{l}\text { listrik pendukung } \\
\text { pemasaran lurik }\end{array}$ & 2 & $\begin{array}{l}\text { Showroom tersedia sambungan listrik secara } \\
\text { langsung dengan daya } 450 \text { VA }\end{array}$ \\
\hline & lurik & & 3 & $\begin{array}{l}\text { Showroom tersedia sambungan listrik secara } \\
\text { langsung dengan daya } 900 \mathrm{VA}\end{array}$ \\
\hline & & $\begin{array}{l}\text { Penyediaan } \text { jaringan } \\
\text { listrik pendukung }\end{array}$ & 1 & $\begin{array}{l}\text { Tersedia jaringan distribusi sekunder dan tidak } \\
\text { tersedia penerangan }\end{array}$ \\
\hline & & pemasaran lurik & 2 & $\begin{array}{l}\text { Tersedia jaringan distribusi primer dan sekunder } \\
\text { serta penerangan }\end{array}$ \\
\hline & & & 3 & $\begin{array}{l}\text { Tersedia jaringan transmisi, distribusi primer dan } \\
\text { sekunder serta penerangan }\end{array}$ \\
\hline & & $\begin{array}{l}\text { Kebutuhan listrik } \\
\text { pemasaran lurik }\end{array}$ & 1 & $\begin{array}{l}\text { Ketersediaan listrik < kebutuhan listrik showroon } \\
\text { dan ketersediaan listrik showroom }<\text { kebutuhan } \\
\text { listrik pengunjung }\end{array}$ \\
\hline & & & 2 & Ketersediaan listrik = kebutuhan listrik showroon \\
\hline
\end{tabular}




\begin{tabular}{|c|c|c|c|c|}
\hline Variabel & Sub Variabel & Indikator & Skor & Tolok Ukur \\
\hline \multirow{6}{*}{$\begin{array}{l}\text { Jaringan } \\
\text { pembuang } \\
\text { an air }\end{array}$} & \multirow{6}{*}{$\begin{array}{l}\text { Jaringan } \\
\text { pembuangan } \\
\text { air pendukung } \\
\text { produksi lurik }\end{array}$} & \multirow{5}{*}{$\begin{array}{l}\text { Pengolah limbah } \\
\text { produksi lurik }\end{array}$} & & $\begin{array}{l}\text { dan ketersediaan listrik showroom = kebutuhan } \\
\text { listrik pengunjung }\end{array}$ \\
\hline & & & 3 & $\begin{array}{l}\text { Ketersediaan listrik }>\text { kebutuhan listrik showroon } \\
\text { dan ketersediaan listrik showroom }>\text { kebutuhan } \\
\text { listrik pengunjung }\end{array}$ \\
\hline & & & 1 & $\begin{array}{l}\text { Pelaku industri lurik tidak melakukan pengolahan } \\
\text { limbah dan lansgung membuang limbah di sungai }\end{array}$ \\
\hline & & & 2 & $\begin{array}{l}\text { Pelaku industri lurik menampung limbah dan } \\
\text { melakukan pengolahan limbah secara individu }\end{array}$ \\
\hline & & & 3 & $\begin{array}{l}\text { Pelaku industri lurik terjangkau pipa jaringan } \\
\text { limbah dan tersedia bangunan pengolah limbah } \\
\text { dengan kapasitas mencukupi }\end{array}$ \\
\hline & & $\begin{array}{ll}\text { Jaringan } & \text { drainase } \\
\text { pendukung } & \text { produksi } \\
\text { lurik } & \end{array}$ & 1 & $\begin{array}{l}\text { Tidak tersedia badan penerima air dan Kapasitas } \\
\text { drainase < Debit air hujan }\end{array}$ \\
\hline \multirow{13}{*}{$\begin{array}{l}\text { Jaringan } \\
\text { pembuang } \\
\text { an air }\end{array}$} & $\begin{array}{l}\text { Jaringan } \\
\text { pembuangan }\end{array}$ & $\begin{array}{ll}\text { Jaringan } & \text { drainase } \\
\text { pendukung } & \text { produksi }\end{array}$ & 2 & $\begin{array}{l}\text { Tersedia sumber air permukaan (sungai) dan } \\
\text { Kapasitas drainase = Debit air hujan }\end{array}$ \\
\hline & $\begin{array}{l}\text { air pendukung } \\
\text { produksi lurik }\end{array}$ & lurik & 3 & $\begin{array}{l}\text { Tersedia sumber air permukaan (sungai) dan } \\
\text { sumber air bawah tanah dan Kapasitas drainase > } \\
\text { Debit air hujan }\end{array}$ \\
\hline & \multirow{11}{*}{$\begin{array}{l}\text { Jaringan } \\
\text { pembuangan } \\
\text { air pendukung } \\
\text { pemasaran } \\
\text { lurik }\end{array}$} & $\begin{array}{l}\text { Jaringan air kotor } \\
\text { pendukung produksi } \\
\text { lurik }\end{array}$ & 1 & $\begin{array}{l}\text { Volume jaringan air kotor }<\text { Volume air limbah } \\
\text { domestik dan volume jaringan air kotor }<\text { limbah } \\
\text { produksi lurik }\end{array}$ \\
\hline & & & 2 & $\begin{array}{l}\text { Volume jaringan air kotor }=\text { Volume air limbah } \\
\text { domestik dan volume jaringan air kotor }=\text { limbah } \\
\text { produksi lurik }\end{array}$ \\
\hline & & & 3 & $\begin{array}{l}\text { Volume jaringan air kotor > Volume air limbah } \\
\text { domestik dan volume jaringan air kotor }>\text { limbah } \\
\text { produksi lurik }\end{array}$ \\
\hline & & \multirow[t]{3}{*}{$\begin{array}{l}\text { Pengolah limbah } \\
\text { pemasaran lurik }\end{array}$} & 1 & $\begin{array}{l}\text { Showoroom lurik tidak melakukan pengolahan } \\
\text { limbah dan lansgung membuang limbah di sungai }\end{array}$ \\
\hline & & & 2 & $\begin{array}{l}\text { Showoroom lurik menampung limbah dan } \\
\text { melakukan pengolahan limbah secara individu }\end{array}$ \\
\hline & & & 3 & $\begin{array}{l}\text { Showoroom lurik terjangkau pipa jaringan limbah } \\
\text { dan tersedia bangunan pengolah limbah dengan } \\
\text { kapasitas mencukupi }\end{array}$ \\
\hline & & \multirow{3}{*}{$\begin{array}{l}\text { Jaringan drainase } \\
\text { pendukung } \\
\text { pemasaran lurik }\end{array}$} & 1 & $\begin{array}{l}\text { Tidak tersedia badan penerima air dan Kapasitas } \\
\text { drainase < Debit air hujan }\end{array}$ \\
\hline & & & 2 & $\begin{array}{l}\text { Tersedia sumber air permukaan (sungai) dan } \\
\text { Kapasitas drainase = Debit air hujan }\end{array}$ \\
\hline & & & 3 & $\begin{array}{l}\text { Tersedia sumber air permukaan (sungai) dan } \\
\text { sumber air bawah tanah dan Kapasitas drainase > } \\
\text { Debit air hujan }\end{array}$ \\
\hline & & \multirow[t]{2}{*}{$\begin{array}{l}\text { Jaringan air kotor } \\
\text { pendukung } \\
\text { pemasaran lurik }\end{array}$} & 1 & $\begin{array}{l}\text { Volume jaringan air kotor < Volume air limbah } \\
\text { domestik pengunjung dan volume jaringan air } \\
\text { kotor < limbah pemasaran lurik }\end{array}$ \\
\hline & & & 2 & $\begin{array}{l}\text { Volume jaringan air kotor }=\text { Volume air limbah } \\
\text { domestik pengunjung dan volume jaringan air }\end{array}$ \\
\hline
\end{tabular}




\begin{tabular}{|c|c|c|c|c|}
\hline Variabel & Sub Variabel & Indikator & Skor & Tolok Ukur \\
\hline \multirow{14}{*}{$\begin{array}{l}\text { Jaringan } \\
\text { telekomun } \\
\text { ikasi }\end{array}$} & \multirow{8}{*}{$\begin{array}{l}\text { Jaringan } \\
\text { telekomunikas } \\
\text { i pendukung } \\
\text { produksi lurik }\end{array}$} & \multirow{5}{*}{$\begin{array}{l}\text { Penyediaan jaringan } \\
\text { telekomunikasi } \\
\text { pendukung produksi } \\
\text { lurik }\end{array}$} & & kotor $=$ limbah pemasaran lurik \\
\hline & & & 3 & $\begin{array}{l}\text { Volume jaringan air kotor }>\text { Volume air limbah } \\
\text { domestik pengunjung dan volume jaringan air } \\
\text { kotor }>\text { limbah pemasaran lurik }\end{array}$ \\
\hline & & & 1 & Tidak tersedia jaringan telekomunikasi \\
\hline & & & 2 & $\begin{array}{l}\text { Tersedia jaringan telepon seluler yang mampu } \\
\text { menjangkau kawasan }\end{array}$ \\
\hline & & & 3 & $\begin{array}{l}\text { Tersedia jaringan telepon kabel dan telepon seluler } \\
\text { yang mampu menjangkau kawasan }\end{array}$ \\
\hline & & \multirow{3}{*}{$\begin{array}{l}\text { Kebutuhan jaringan } \\
\text { telekomunikasi } \\
\text { pendukung produsksi } \\
\text { lurik }\end{array}$} & 1 & Tidak tersedia jaringan telekomunikasi \\
\hline & & & 2 & $\begin{array}{l}\text { Jaringan telepon seluler mampu melayani akses } \\
\text { internet, telepon dan sms bagi pengrajin lurik }\end{array}$ \\
\hline & & & 3 & $\begin{array}{l}\text { Ketersediaan sambungan telepon }>\text { Kebutuhan } \\
\text { sambungan telepon dan Jaringan telepon seluler } \\
\text { mampu melayani akses internet, telepon dan sms } \\
\text { bagi pengrajin lurik }\end{array}$ \\
\hline & \multirow{6}{*}{$\begin{array}{l}\text { Jaringan } \\
\text { telekomunikas } \\
\text { i pendukung } \\
\text { pemasaran } \\
\text { lurik }\end{array}$} & \multirow{3}{*}{$\begin{array}{l}\text { Penyediaan jaringan } \\
\text { telekomunikasi } \\
\text { pendukung } \\
\text { pemasaran lurik }\end{array}$} & 1 & Tidak tersedia jaringan telekomunikasi \\
\hline & & & 2 & $\begin{array}{l}\text { Tersedia jaringan telepon seluler dengan } 3 \\
\text { provider yang mampu menjangkau kawasan }\end{array}$ \\
\hline & & & 3 & $\begin{array}{l}\text { Tersedia jaringan telepon kabel dan telepon seluler } \\
\text { dengan } 3 \text { provider yang mampu menjangkau } \\
\text { kawasan }\end{array}$ \\
\hline & & \multirow{3}{*}{$\begin{array}{l}\text { Kebutuhan jaringan } \\
\text { telekomunikasi } \\
\text { pendukung } \\
\text { pemasaran lurik }\end{array}$} & 1 & Tidak tersedia jaringan telekomunikasi \\
\hline & & & 2 & $\begin{array}{l}\text { Jaringan telepon seluler mampu melayani akses } \\
\text { internet, telepon dan sms bagi showroom dan } \\
\text { pengunjung }\end{array}$ \\
\hline & & & 3 & $\begin{array}{l}\text { Ketersediaan sambungan telepon > Kebutuhan } \\
\text { sambungan telepon dan Jaringan telepon seluler } \\
\text { mampu melayani akses internet, telepon dan sms } \\
\text { bagi showroom dan pengunjung }\end{array}$ \\
\hline
\end{tabular}

\subsection{Analisis skoring ketersediaan infrastruktur kawasan industri lurik}

Pada penelitian ini digunakan teknik analisis skoring (lihat Gambar 1). Skoring yang disebut juga sebagai skor skala, pada dasarnya interpretasi skor skala selalu bersifat normatif. Apabila pengukuran atau pembobotan indikator menggunakan kuisioner maka dapat dicari dengan perhitungan sebagai berikut.

$$
\text { Rata }- \text { rata }(\text { mean }) \text { tiap parameter }=\frac{\sum(\text { Skor indikator } \times \text { jumlah responden })}{\text { Total responden }}
$$

Namun, apabila pembobotan dilakukan dengan hasil observasi primer dan survey data sekunder, pembobotan skor dapat dilakukan dengan mencocokan hasil data observasi primer dan survey data sekunder dengan parameter yang telah ditentukan pada variabel operasional. Kemudian untuk menghitung skor dari setiap sub variabel didapatkan dari nilai rata-rata skor parameter yang dapat dihitung menggunakan rumus sebagai berikut: 


$$
\text { Rata }- \text { rata (mean) tiap sub variabel }=\frac{\sum(\text { Skor parameter })}{\text { Jumlah parameter }}
$$

Berdasarkan skor setiap sub variabel maka dapat diperoleh skor ketersediaan setiap variabel dengan menjumlahkan skor setiap sub variabel kemudian dibagi dengan jumlah sub variabel.

$$
\text { Rata }- \text { rata (mean) tiap variabel }=\frac{\sum(\text { Skor Sub variabel })}{\text { Jumlah sub variabel }}
$$

Hasil perhitungan skor dari setiap variabel mewakili ketersediaan setiap infrastruktur terhadap kegiatan di kawasan industri lurik ATBM Desa Tlingsing, sedangkan ketersediaan infrastruktur ditentukan berdasarkan perhitungan interval indikator kesiapan yaitu:

$$
\text { Interval }=(X \max -X \min ) / \text { Kelas Interval }
$$

Setelah ditetapkan nilai interval, maka dapat diketahui kategori ketersediaan infrastruktur pada

\begin{tabular}{|c|c|c|c|c|c|c|}
\hline \multirow[t]{2}{*}{ Variabel } & \multirow{2}{*}{$\begin{array}{l}\text { Skor } \\
\text { Maksimum }\end{array}$} & \multirow{2}{*}{$\begin{array}{l}\text { Skor } \\
\text { Minimum }\end{array}$} & \multirow[t]{2}{*}{ Interval } & \multicolumn{3}{|c|}{ Skor } \\
\hline & & & & $\begin{array}{c}\text { Sangat } \\
\text { Memenuhi } \\
(3)\end{array}$ & $\begin{array}{l}\text { Memenuhi } \\
\text { (2) }\end{array}$ & $\begin{array}{c}\text { Tidak } \\
\text { Memenuhi } \\
(1)\end{array}$ \\
\hline Jaringan jalan & 3 & 1 & 0,6 & 2,4 hingga 3 & 1,7 hingga 2,3 & 1 hingga 1,6 \\
\hline $\begin{array}{l}\text { Jaringan air } \\
\text { bersih }\end{array}$ & 3 & 1 & 0,6 & 2,4 hingga 3 & 1,7 hingga 2,3 & 1 hingga 1,6 \\
\hline Jaringan listrik & 3 & 1 & 0,6 & 2,4 hingga 3 & 1,7 hingga 2,3 & 1 hingga 1,6 \\
\hline $\begin{array}{l}\text { Jaringan } \\
\text { pembuangan air }\end{array}$ & 3 & 1 & 0,6 & 2,4 hingga 3 & 1,7 hingga 2,3 & 1 hingga 1,6 \\
\hline $\begin{array}{l}\text { Jaringan } \\
\text { telekomunikasi }\end{array}$ & 3 & 1 & 0,6 & 2,4 hingga 3 & 1,7 hingga 2,3 & 1 hingga 1,6 \\
\hline
\end{tabular}
Tabel 2.

Tabel 2. Ketentuan skor variabel

Berdasarkan tabel di atas dapat diketahui bahwa infrastrukur dikatakan memenuhi apabila memiliki skor rata-rata minimum 1,7 hingga 2,3. 


\begin{tabular}{|l|l|l|l|}
\hline \multicolumn{1}{|c|}{ Input } & \multicolumn{1}{|c|}{ Proses } & \multicolumn{1}{|c|}{ Output } \\
\hline $\begin{array}{l}\text { Identifikasi } \\
\text { ketersediaan } \\
\text { infrastruktur pada } \\
\text { pusat-pusat kegiatan } \\
\text { kawasan industri lurik }\end{array}$ & $\begin{array}{l}\text { Analisis ketersediaan } \\
\text { infrastruktur dan } \\
\text { pembobotan skor } \\
\text { indikator- indikator } \\
\text { infrastruktur }\end{array}$ & $\begin{array}{l}\text { Skor tiap sub variabel } \\
\text { infrastruktur kawasan } \\
\text { industri lurik }\end{array}$ \\
\hline $\begin{array}{l}\text { Skor tiap sub variabel } \\
\text { infrastruktur kawasan } \\
\text { industri lurik }\end{array}$ & $\begin{array}{l}\text { Analisis skoring sub } \\
\text { variabel infrastruktur } \\
\text { kawasan industri lurik } \\
\text { Desa Tlingsing }\end{array}$ & $\begin{array}{l}\text { Ketersediaan } \\
\text { infrastruktur dalam } \\
\text { memenuhi kebutuhan } \\
\text { untuk kegiatan industri } \\
\text { lurik ATBM saat ini }\end{array}$ \\
\hline
\end{tabular}

Gambar 1. Kerangka analisis.

\section{Hasil dan pembahasan}

\subsection{Identifikasi Pusat Kegiatan Industri Lurik ATBM}

Desa Tlingsing merupakan salah satu desa di Kecamatan Cawas Kabupaten Klaten yang terkenal dengan industri lurik ATBM. Desa Tlingsing merupakan sentra industri lurik ATBM terbesar di Kabupaten Klaten. Kegiatan di kawasan industri lurik ATBM di Desa Tlingsing meliputi proses produksi dan proses pemasaran. Proses produksi meliputi pemilihan bahan baku, pewarnaan, penjemuran benang, ngeklos, nyekir, ngebum, nyucuk dan proses menenun. Pada kegiatan pemilihan bahan baku dilakukan di Pasar Pedan dan Pasar Cawas sedangkan, untuk pengolahan bahan baku dilakukan di setiap rumah pengrajin di Desa Tlingsing. Proses pemasaran dilakukan di showroom yang ada di Desa Tlingsing serta dilakukan promosi produk secara online. Agar mampu kegiatan produksi dan kegiatan pemasaran dapat berjalan dengan baik diperlukan ketersediaan infrastruktur yang mampu memenuhi kebutuhan kawasan industri. Lokasi pusat kegiatan industri lurik ATBM dapat dilihat pada Gambar 2. 


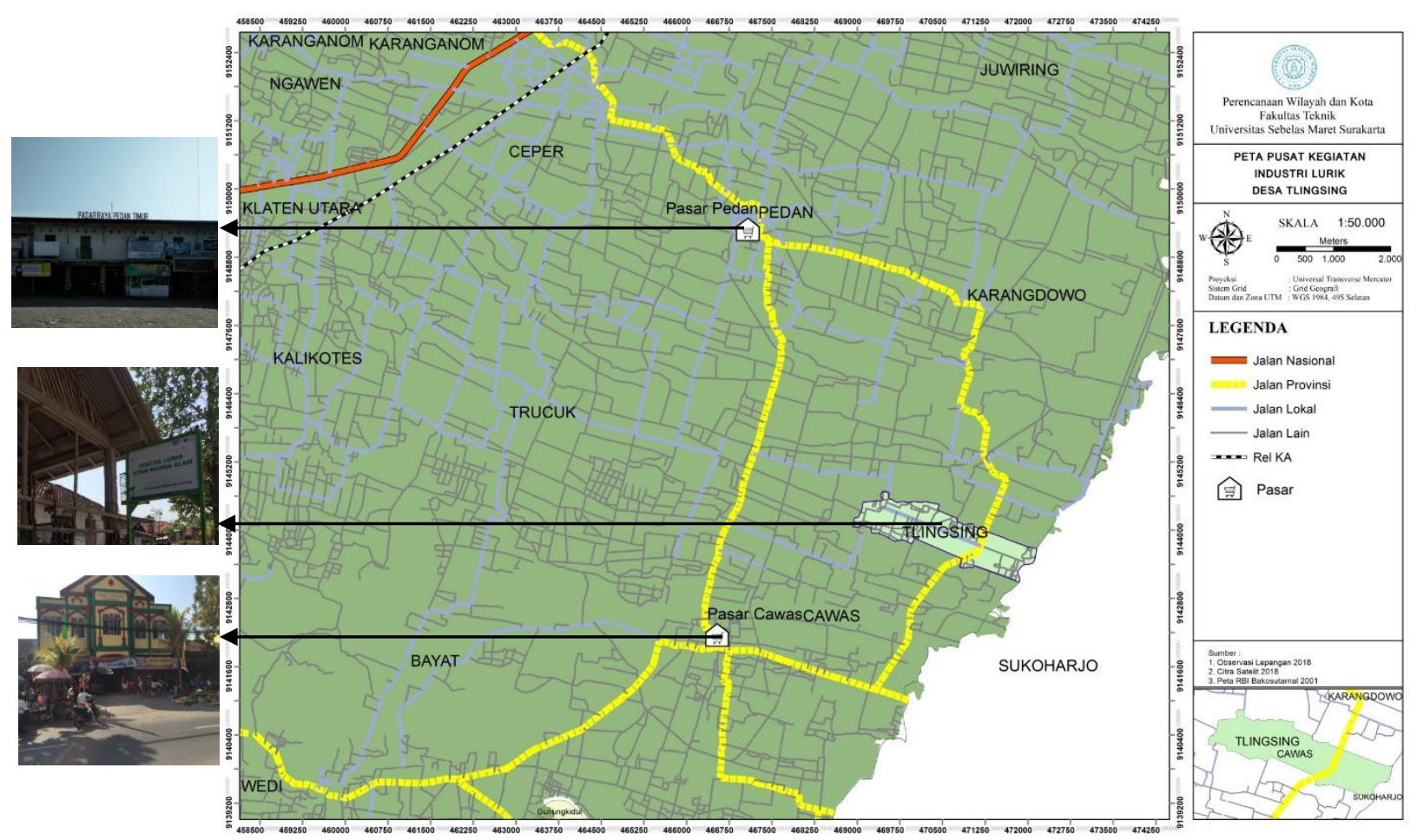

Gambar 2. Pusat kegiatan industri lurik ATBM

\subsection{Ketersediaan infrastruktur kawasan industri lurik atbm}

Untuk mengetahui ketersediaan infrastruktur kawasan indsutri lurik dilakukan dengan mencocokan kondisi eksisting dengan parameter yang telah disusun kemudian dilakukan pembobotan skor berdasarkan parameter tersebut. Berdasarkan hasil observasi dan pengisian kuisioner, dapat diketahui kondisi eksisting infrastruktur di Desa Tlingsing pada Tabel 3.

Tabel 3. Pembobotan skor indikator ketersediaan infrastruktur

\begin{tabular}{|c|c|c|c|c|}
\hline Variabel & Sub Variabel & Indikator & Kondisi Eksisting & Skor \\
\hline \multirow{4}{*}{ Jaringan jalan } & $\begin{array}{l}\text { Jaringan jalan } \\
\text { pendukung } \\
\text { produksi }\end{array}$ & Badan jalan & $\begin{array}{l}\text { Seluruh ruas jalan menuju lokasi sumber bahan } \\
\text { baku yakni } 3 \text { ruas jalan memiliki bahu jalan 0,5 } \\
\text { meter dan pembagian } 2 \text { jalur jalan. Namun } 2 \text { ruas } \\
\text { jalan provinsi (jalan utama) memiliki lebar } 5 \\
\text { meter dan jalan lokal 2,5 meter }\end{array}$ & 1 \\
\hline & & $\begin{array}{l}\text { Perlengkap-an } \\
\text { jalan }\end{array}$ & $\begin{array}{l}\text { Seluruh ruas jalan menuju lokasi bahan baku } \\
\text { memiliki rambu penunjuk arah menuju lokasi } \\
\text { bahan baku, marka dan penerangan jalan }\end{array}$ & 2 \\
\hline & & $\begin{array}{l}\text { Kapasitas } \\
\text { jalan }\end{array}$ & $\begin{array}{l}\text { Seluruh ruas jalan menuju sumber bahan baku } \\
\text { memiliki tingkat pelayanan jalan kategori } A\end{array}$ & 3 \\
\hline & $\begin{array}{l}\text { Jaringan jalan } \\
\text { pendukung } \\
\text { pemasaran }\end{array}$ & Badan jalan & $\begin{array}{l}\text { Seluruh ruas jalan yakni } 16 \text { ruas jalan menuju } \\
\text { lokasi transit terdekat memiliki bahu jalan } 0,5 \\
\text { meter dan pembagian } 2 \text { jalur jalan. Namun } 5 \text { ruas }\end{array}$ & 1 \\
\hline
\end{tabular}

Received : September 21, 2018; Accepted: October 10, 2018; Available online: January 10, 2020 


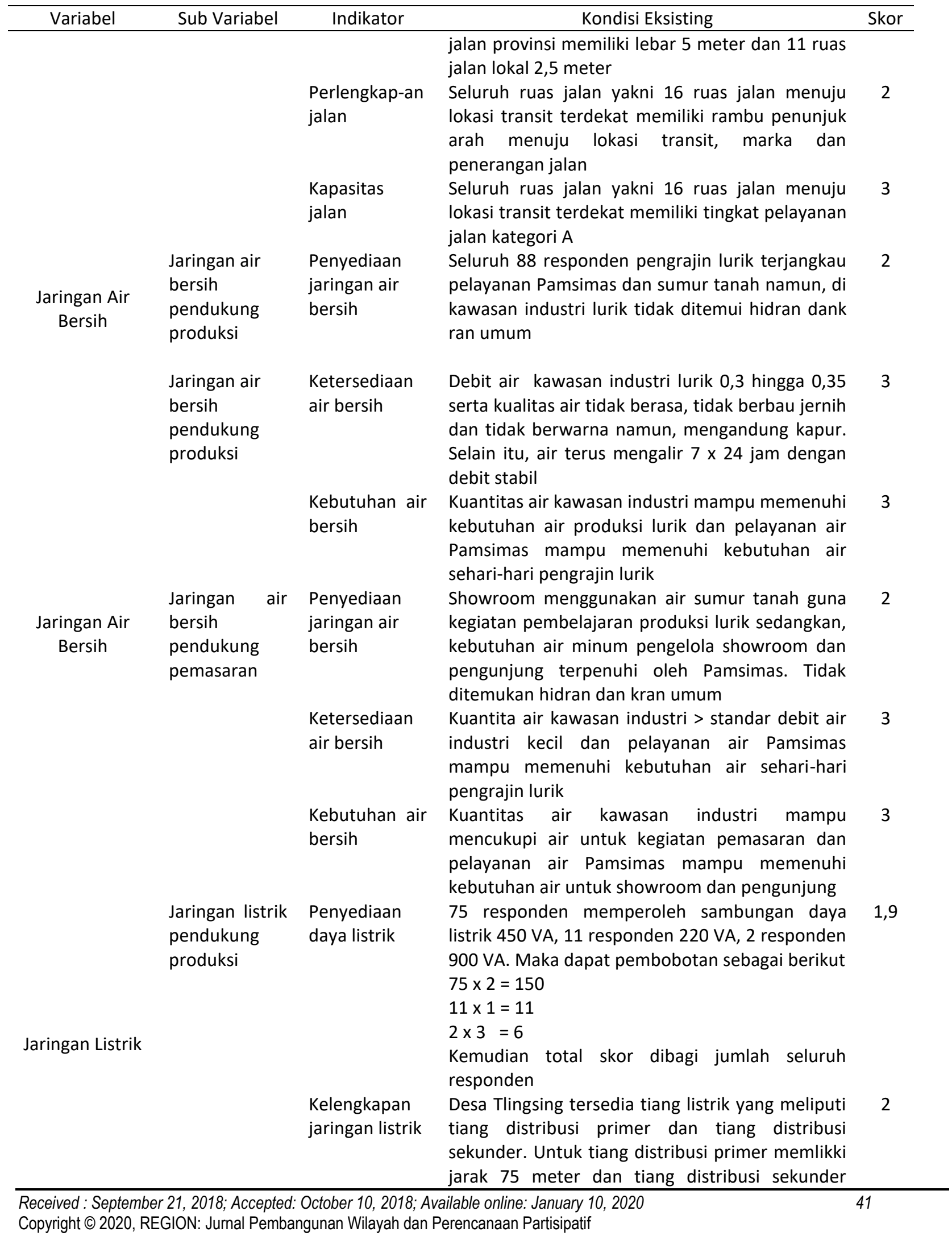




\begin{tabular}{|c|c|c|c|c|}
\hline Variabel & Sub Variabel & Indikator & Kondisi Eksisting & Skor \\
\hline & & & $\begin{array}{lcccc}\text { setiap } 30 & \text { meter dan dilengkapi dengan } \\
\text { penerangan } & & & \\
\end{array}$ & \\
\hline & & $\begin{array}{l}\text { Kebutuhan } \\
\text { listrik }\end{array}$ & $\begin{array}{l}\text { Ketresediaan listrik kawasan lebih besar dari } \\
\text { kebutuhan listrik produksi lurik dan kebutuhan } \\
\text { listrik pengrajin lurik }\end{array}$ & 3 \\
\hline & $\begin{array}{l}\text { Jaringan listrik } \\
\text { pendukung } \\
\text { pemasaran }\end{array}$ & $\begin{array}{l}\text { Penyediaan } \\
\text { daya listrik }\end{array}$ & $\begin{array}{l}\text { Seluruh showroom di kawasan industri lurik } \\
\text { meperoleh sambungan listrik dengan daya } 900 \\
\text { VA }\end{array}$ & 3 \\
\hline & & $\begin{array}{l}\text { Kelengkapan } \\
\text { jaringan listrik }\end{array}$ & $\begin{array}{l}\text { Desa Tlingsing tersedia tiang listrik yang meliputi } \\
\text { tiang distribusi primer dan tiang distribusi } \\
\text { sekunder. Untuk tiang distribusi primer memlikki } \\
\text { jarak } 75 \text { meter dan tiang distribusi sekunder } \\
\text { setiap } 30 \text { meter dan dilengkapi dengan } \\
\text { penerangan }\end{array}$ & 2 \\
\hline & & $\begin{array}{l}\text { Kebutuhan } \\
\text { listrik }\end{array}$ & $\begin{array}{l}\text { Ketersediaan listrik kawasan lebih besar } \\
\text { dibandingkan kebutuhan listrik showroom dan } \\
\text { pengunjung }\end{array}$ & 3 \\
\hline & $\begin{array}{l}\text { Jaringan } \\
\text { pembuangan } \\
\text { air pendukung } \\
\text { produksi }\end{array}$ & $\begin{array}{l}\text { Jaringan } \\
\text { pengolah } \\
\text { limbah }\end{array}$ & $\begin{array}{l}\text { Sebanyak } 78 \text { responden lansgung membuang } \\
\text { limbah hasil produksi ke sungai dan } 10 \\
\text { responden mengolah limbah terlebih dahulu } \\
\text { kemudian dibuang ke sungai. Sehingga dapat } \\
\text { dilakukan perhitungan berikut } \\
78 \times 1=78 \\
10 \times 2=20 \text {. } \\
\text { Skor rata } 98 \text { dibagi jumlah selruh responden }\end{array}$ & 1,1 \\
\hline \multirow{4}{*}{$\begin{array}{l}\text { Jaringan } \\
\text { Pembuangan } \\
\text { Air }\end{array}$} & & $\begin{array}{l}\text { Jaringan } \\
\text { drainase }\end{array}$ & $\begin{array}{l}\text { Berdasarkan hasil perhitungan dengan } \\
\text { persamaan manning, volume sungai dan saluran } \\
\text { drainase tidak mampu menampung debit air } \\
\text { hujan. Berdasarkan pengisian kuisioner seluruh }\end{array}$ & 1 \\
\hline & & & $\begin{array}{l}\text { responden menyatakan Desa Tlingsing sering } \\
\text { mengalami banjir. Hal tersebut diperkuat dengan } \\
\text { peta rawan bencana banjir dimana Desa Tlingsing } \\
\text { merupakan daerah rawan bencana banjir }\end{array}$ & \\
\hline & & $\begin{array}{l}\text { Jaringan air } \\
\text { kotor }\end{array}$ & $\begin{array}{l}\text { Volume saluran air kotor yang sekaligus saluran } \\
\text { drainase mampu menampung air limbah } \\
\text { domestic pengrajin lurik }\end{array}$ & 3 \\
\hline & $\begin{array}{l}\text { Jaringan } \\
\text { pembuang-an } \\
\text { air pendukung } \\
\text { pemasaran }\end{array}$ & $\begin{array}{l}\text { Jaringan } \\
\text { pengolah } \\
\text { limbah }\end{array}$ & $\begin{array}{l}\text { Seluruh showroom lurik tidak mengolah limbah } \\
\text { dan langsung dibuang ke sungai }\end{array}$ & 1 \\
\hline $\begin{array}{l}\text { Jaringan } \\
\text { Pembuangan } \\
\text { Air }\end{array}$ & $\begin{array}{l}\text { Jaringan } \\
\text { pembuang-an } \\
\text { air pendukung } \\
\text { pemasaran }\end{array}$ & $\begin{array}{l}\text { Jaringan } \\
\text { drainase }\end{array}$ & $\begin{array}{l}\text { Berdasarkan hasil perhitungan dengan } \\
\text { persamaan manning, volume sungai dan saluran } \\
\text { drainase tidak mampu menampung debit air } \\
\text { hujan. Berdasarkan pengisian kuisioner seluruh } \\
\text { responden menyatakan Desa Tlingsing sering } \\
\text { mengalami banjir. Hal tersebut diperkuat dengan }\end{array}$ & 1 \\
\hline . & & & ary 10, 2020 & 42 \\
\hline
\end{tabular}




\begin{tabular}{|c|c|c|c|c|}
\hline Variabel & Sub Variabel & Indikator & Kondisi Eksisting & Skor \\
\hline \multirow{5}{*}{$\begin{array}{l}\text { Jaringan } \\
\text { Telekomuni- } \\
\text { kasi }\end{array}$} & \multirow{3}{*}{$\begin{array}{l}\text { Jaringan } \\
\text { telekomuni- } \\
\text { kasi } \\
\text { pendukung } \\
\text { produksi }\end{array}$} & $\begin{array}{l}\text { Jaringan } \\
\text { kotor }\end{array}$ & $\begin{array}{l}\text { peta rawan bencana banjir dimana Desa Tlingsing } \\
\text { merupakan daerah rawan bencana banjir } \\
\text { Volume jaringan air kotor yang sekaligus jaringan } \\
\text { drainase mampu memiliki volume yang lebih } \\
\text { besar dibandingkan air limbah domestic dari } \\
\text { pengunjung dan showroom }\end{array}$ & 3 \\
\hline & & $\begin{array}{l}\text { Penyediaan } \\
\text { jaringan } \\
\text { telekomuni- } \\
\text { kasi }\end{array}$ & $\begin{array}{l}\text { Sebanyak } 88 \text { responden menyatakan bahwa tidak } \\
\text { tersedia jaringan telepon kabel namun, kawasan } \\
\text { terjangkau pelayanan telepon seluler }\end{array}$ & 2 \\
\hline & & $\begin{array}{l}\text { Kebutuhan } \\
\text { sambungan } \\
\text { telekomuni- } \\
\text { kasi }\end{array}$ & $\begin{array}{l}\text { Sebanyak } 88 \text { responden pengrajin lurik terlayani } \\
\text { oleh jaringan telepon seluler yang mampu } \\
\text { melayani akses internet, telepon dan sms }\end{array}$ & 2 \\
\hline & $\begin{array}{l}\text { Jaringan } \\
\text { telekomuni- } \\
\text { kasi } \\
\text { pendukung }\end{array}$ & $\begin{array}{l}\text { Penyediaan } \\
\text { jaringan } \\
\text { telekomuni- } \\
\text { kasi }\end{array}$ & $\begin{array}{l}\text { Showroom lurik dan pengunjung hanya } \\
\text { terjnagakau oleh layanan telepon seluler }\end{array}$ & 2 \\
\hline & pemasaran & $\begin{array}{l}\text { Kebutuhan } \\
\text { sambungan } \\
\text { ttelekomuni- } \\
\text { kasi }\end{array}$ & $\begin{array}{l}\text { Seluruh showroom dan pengunjung terlayani } \\
\text { oleh jaringan telepon seluler dengan akses } \\
\text { internet, telepon dan sms }\end{array}$ & 2 \\
\hline
\end{tabular}

Berdasarkan pembobotan indikator di atas dapat dilakukan skoring ketersediaan infrastruktur guna memenuhi kebutuhan kawasan industri lurik ATBM saat ini. Hasil pembobotan indikator pada setiap infrastruktur sebelumnya dapat disusun tabel hasil skoring seperti terlihat pada Tabel 4.

Berdasarkan analisis skoring yang tercantum pada Tabel 4, dapat diketahui bahwa jaringan air bersih dan jaringan listrik sangat memenuhi kebutuhan untuk kegiatan produksi dan kegiatan pemasaran lurik ATBM saat ini. Hal tersebut dapat dilihat dari indikator dari jaringan air bersih dan jaringan listrik yang seluruhnya memenuhi standar yang berlaku saat ini. Peta jaringan air bersih dan jaringan listrik dapat dilihat di Gambar 3 dan Gambar 4.

Pada jaringan jalan, ketersediaan tergolong memenuhi kegiatan produksi dan pemasaran lurik ATBM saat ini. Hal tersebut karena terdapat satu indikator yakni badan jalan yang tidak memenuhi standar yang berlaku saat ini. Namun, berdasarkan hasil pengisian kuisioner, seluruh pengrajin lurik dan pengunjung tidak terganggu dengan badan jalan yang tidak sesuai dengan standar yang berlaku saat ini. Pengrajin dan pengunjug menyatakan bahwa kondisi badan jalan saat ini sudah sangat memenuhi kebutuhan pergerakan di kawasan industri lurik ATBM saat ini. Sehingga dapat dikatakan bahwa jaringan jalan tergolong sangat memenuhi kebutuhan untuk pergerakan di kawasan industri lurik ATBM saat ini. Peta jaringan jalan di Desa Tlingsing dapat dilihat di gambar 5 dan Gambar 6. 
Tabel 4. Ketersediaan Infrastruktur Kawasan Industri Lurik

\begin{tabular}{|c|c|c|c|c|}
\hline Variabel & Sub Variabel & $\begin{array}{l}\text { Skor Sub } \\
\text { Variabel }\end{array}$ & $\begin{array}{c}\text { Skor } \\
\text { Variabel }\end{array}$ & Keterangan \\
\hline \multirow[t]{2}{*}{ Jaringan jalan } & Jaringan jalan pendukung produksi lurik & 2 & 2 & Memenuhi \\
\hline & Jaringan jalan pendukung pemasaran lurik & 2 & & \\
\hline \multirow{2}{*}{$\begin{array}{l}\text { Jaringan air } \\
\text { bersih }\end{array}$} & Jaringan air bersih pendukung produksi lurik & 2,6 & 2,6 & Sangat \\
\hline & Jaringan air bersih pendukung pemasaran lurik & 2,6 & & \\
\hline \multirow[t]{2}{*}{ Jaringan listrik } & Jaringan listrik pendukung produksi lurik & 2,3 & 2,45 & Sangat \\
\hline & Jaringan listrik pendukung pemasaran lurik & 2,6 & & memenuhi \\
\hline \multirow[t]{2}{*}{$\begin{array}{l}\text { Jaringan } \\
\text { pembuangan air }\end{array}$} & $\begin{array}{l}\text { Jaringan pembuang air pendukung produksi } \\
\text { lurik }\end{array}$ & 1,7 & 1,65 & $\begin{array}{l}\text { Tidak } \\
\text { Memenuhi }\end{array}$ \\
\hline & $\begin{array}{l}\text { Jaringan pembuang air pendukung pemasaran } \\
\text { lurik }\end{array}$ & 1,6 & & \\
\hline \multirow[t]{2}{*}{$\begin{array}{l}\text { Jaringan } \\
\text { Telekomunikasi }\end{array}$} & $\begin{array}{l}\text { Jaringan telekomunikasi pendukung produksi } \\
\text { lurik }\end{array}$ & 2 & 2 & Memenuhi \\
\hline & $\begin{array}{l}\text { Jaringan telekomunikasi pendukung pemsaran } \\
\text { lurik }\end{array}$ & 2 & & \\
\hline
\end{tabular}

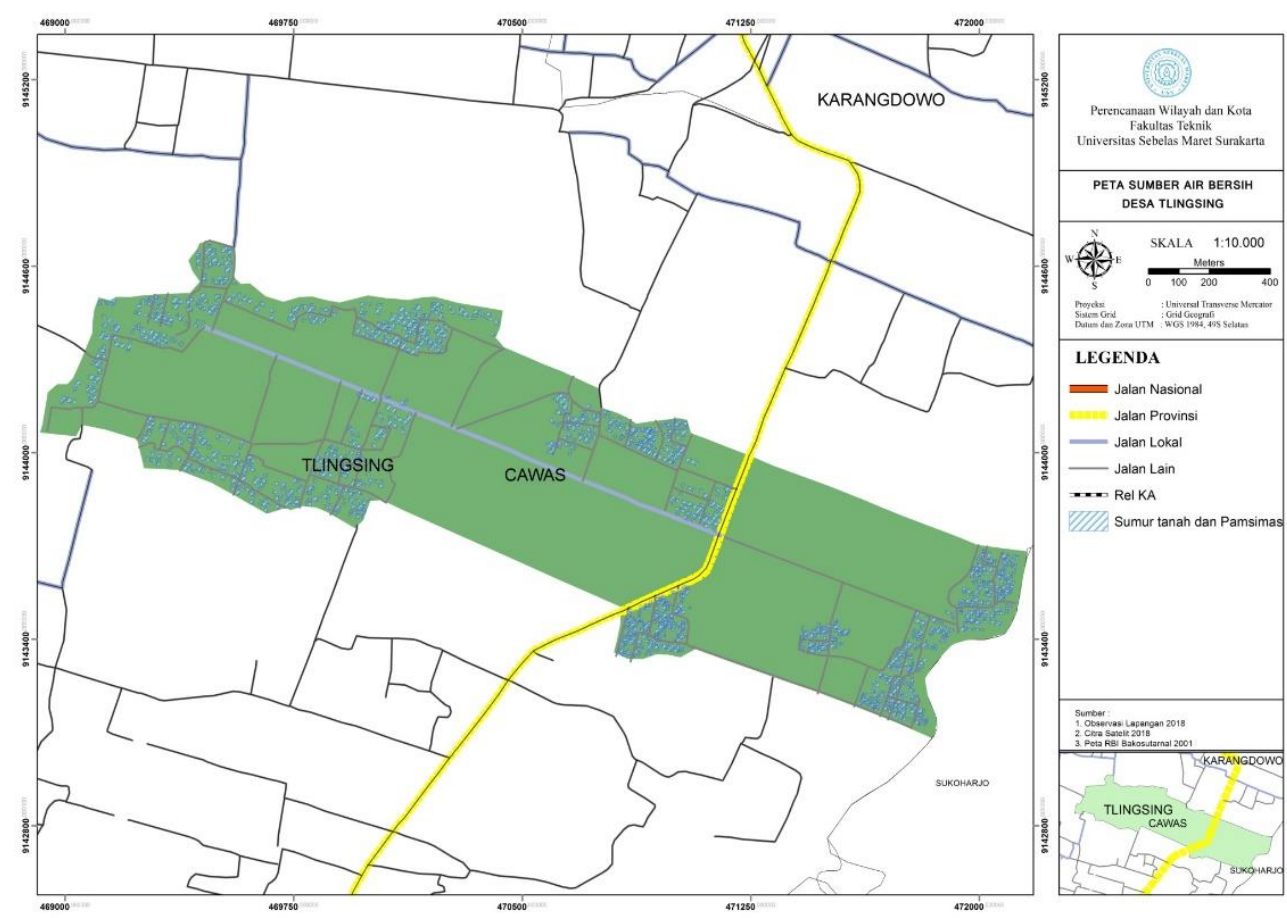

Gambar 3. Jaringan air bersih Desa Tlingsing 


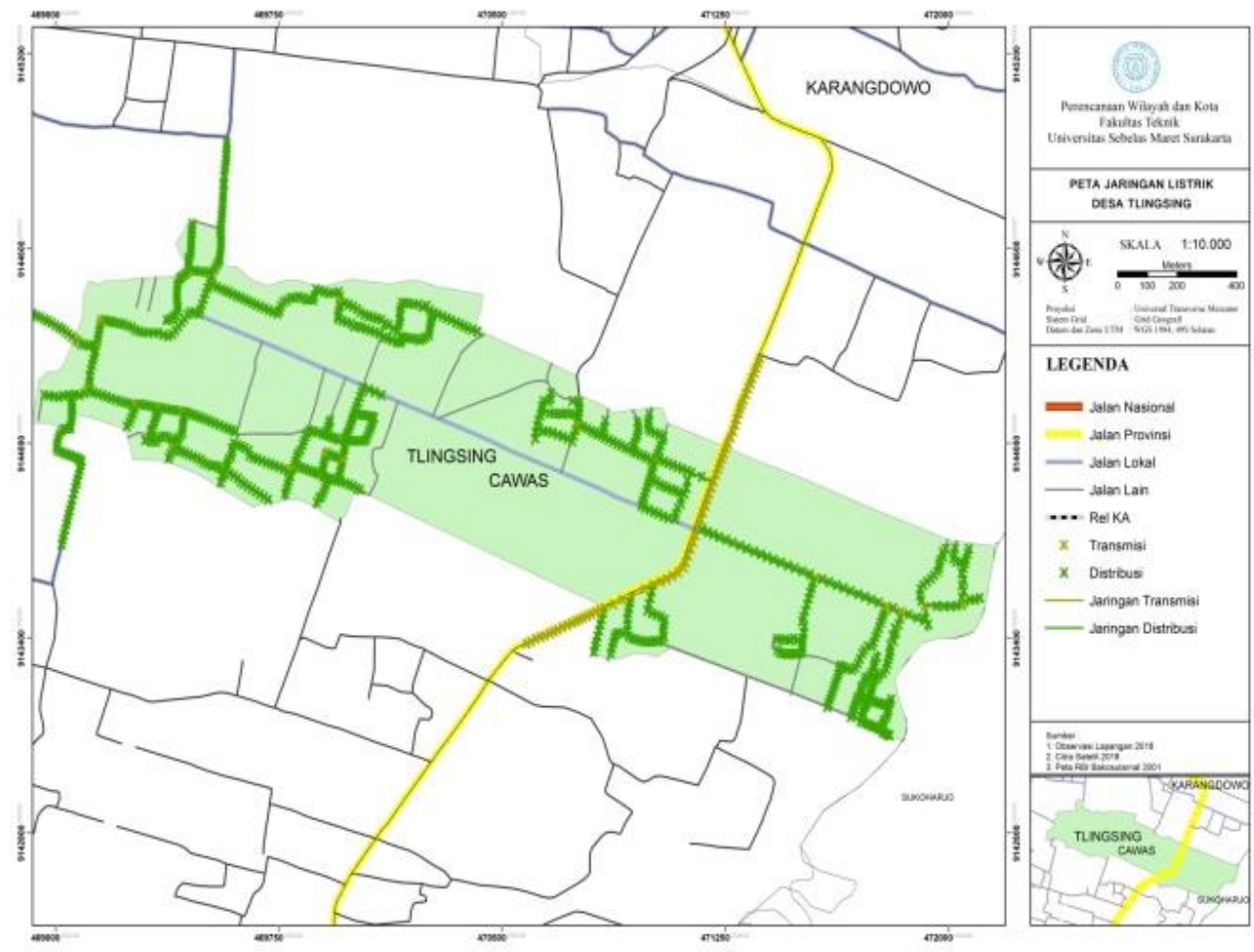

Gambar 4. Jaringan listrik Desa Tlingsing

Pada jaringan telekomunikasi, ketersediaan tergolong memenuhi kegiatan produksi dan pemasaran lurik ATBM saat ini. Hal tersebut ditinjau dari kedua indikator jaringan telekomunikasi yakni penyediaan jaringan telekomunikasi dan kebutuhan sambungan telekomunikasi yang hanya memenuhi standar minimal yang berlaku saat ini.Sehingga ketersediaan jaringan telekomunikasi tergolong memenuhi untuk kebutuhan produksi dan pemasaran lurik ATBM saat ini. Peta jaringan telekomunikasi dapat dilihat di Gambar 7.

Pada jaringan pembuangan air, ketersediaan tergolong tidak memenuhi kebutuhan kawasan industri lurik. Hal tersebut karena, hanya terdapat satu indikator yang memenuhi standar yakni ketersediaan jaringan air kotor yang menampung limbah domestik yang dihasilkan pengrajin lurik dan pengunjung. Namun, untuk indikator yang lain tidak memenuhi standar yang berlaku karena tidak tersedianya bangunan pengolah limbah dan jaringan drainase yang berperan juga sebagai jaringan air kotor tidak mampu menampung debit air hujan. 


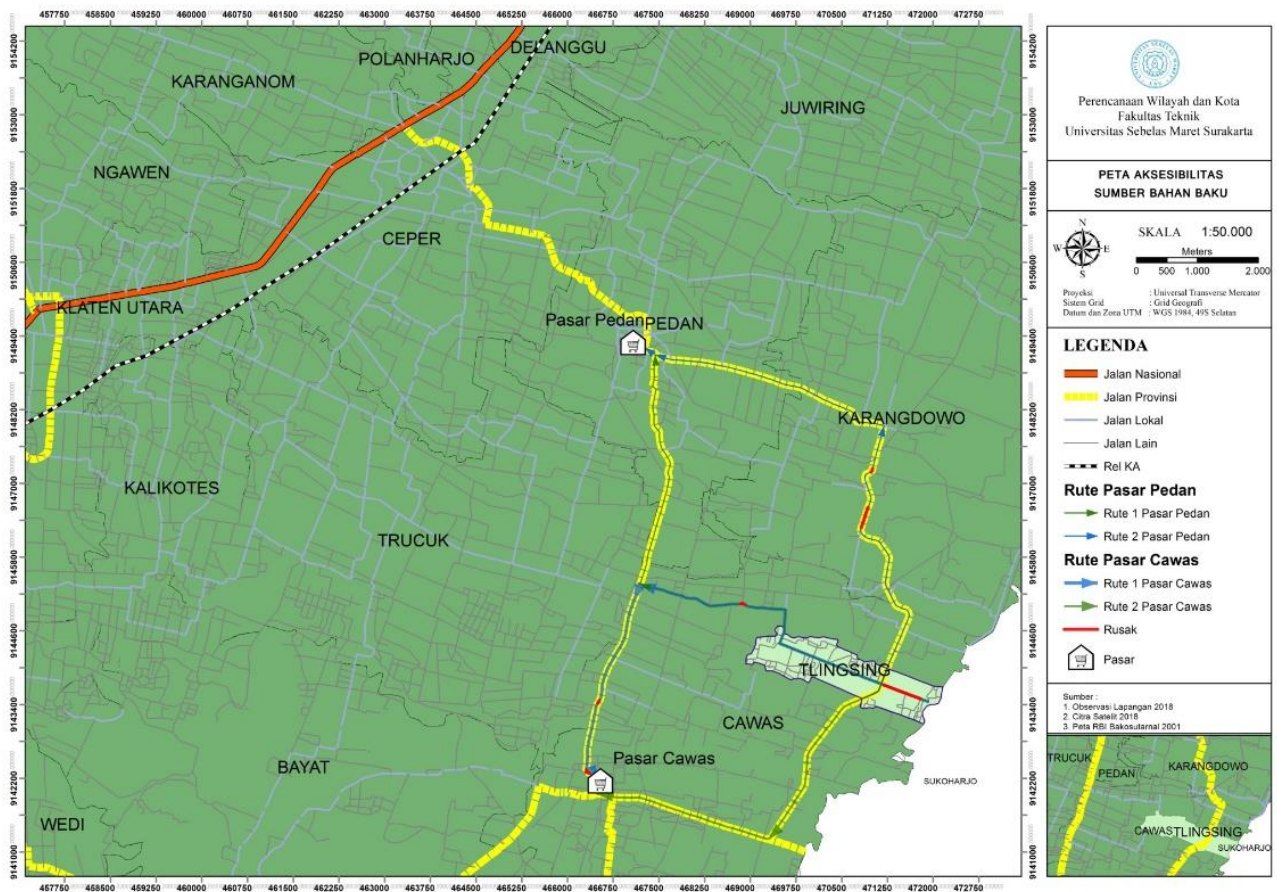

Gambar 5. Jaringan jalan menuju lokasi bahan baku

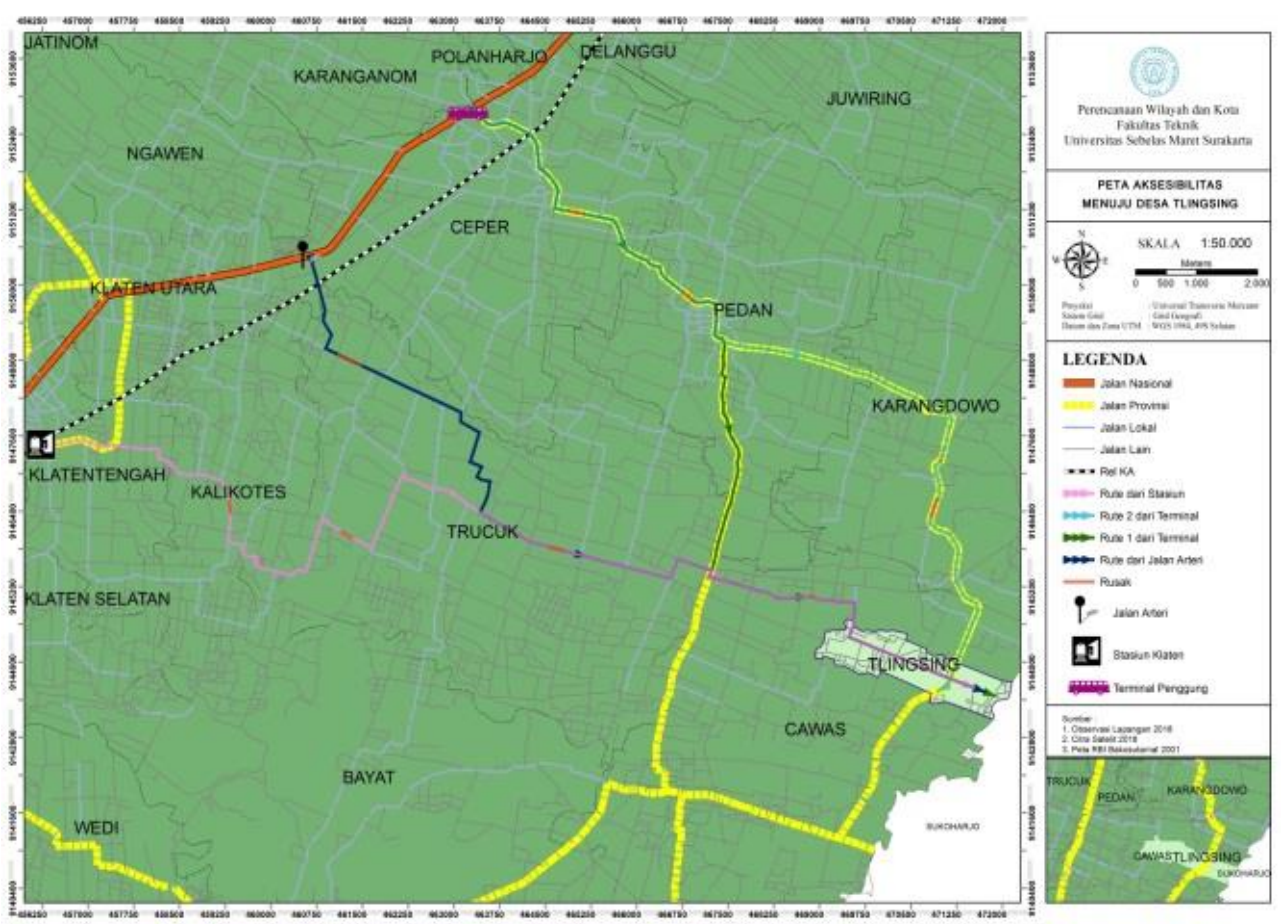

Gambar 6. Jaringan jalan menuju lokasi transit 


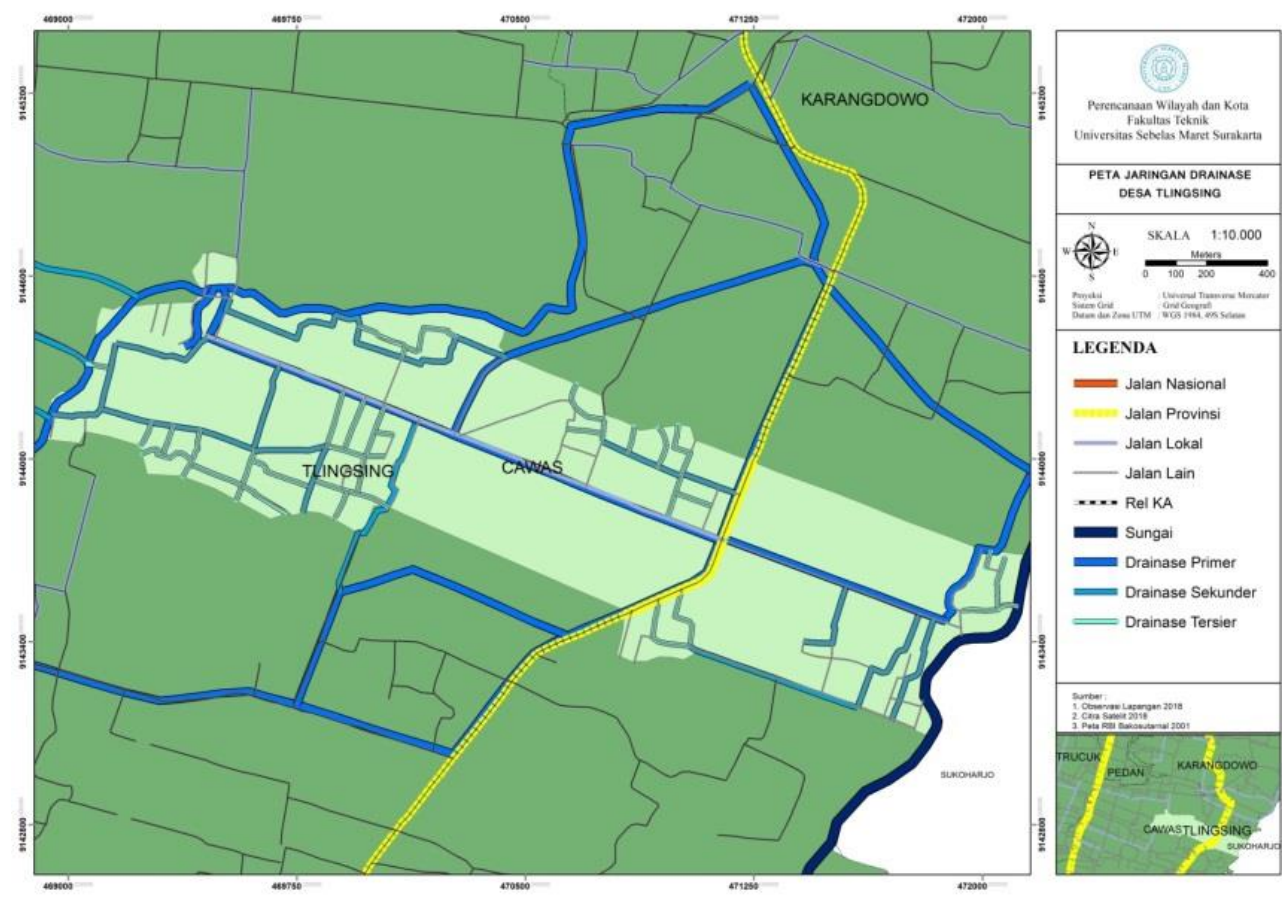

Gambar 7. Jaringan drainase Desa Tlingsing

\section{Kesimpulan}

Kawasan industri secara umum memerlukan prasarana pergerakan barang dan manusia, jaringan air bersih, penyuplai energi, jaringan pengolah limbah, jaringan drainase, jaringan air kotor, jaringan telekomunikasi serta fasilitas sosial dan fasilitas umum [3, 8, 11]. Kawasan industri lurik ATBM Desa Tlingsing, tersedia jaringan jalan, jaringan air bersih, jaringan listrik, jaringan pembuangan air dan jaringan telekomunikasi. Seluruh infrastruktur dapat memenuhi kebutuhan kawasan industri lurik saat ini kecuali, jaringan pembuangan air. Pada jaringan pembuangan salah satu komponen jaringan pembuangan air tidak tersedia yakni jaringan pengolah limbah. Selain itu, jaringan drainase juga tidak mampu menampung debit air hujan di kawasan industri lurik. Berdasarkan hal tersebut diperlukan pengembangan yang difokuskan pada jaringan pengolah limbah dan jaringan drainase agar dapat berfungsi optimal. Sedangkan, pada jaringan jalan, jaringan air bersih, jaringan listrik dan jaringan telekomunikasi dilakukan pemeliharaan agar tidak mengalami penurunan fungsi.

\section{Ucapan Terima Kasih}

Segala puji syukur kehadirat Tuhan Yesus Kristus, atas kasih karuniaNya penulis dapat menyelesaikan penelitian ini. Penulis juga mengucapkan terima kasih atas bimbingan, dukungan, dan partisipasi kepada pihak yang terlibat dalam penelitian ini. 


\section{Referensi}

[1] Undang-undang Republik Indonesia Nomor 3 Tahun 2014 tentang Perindustrian Diakses dari https://kemenperin.go.id/download/5181/Undang-Undang-No-3-Tahun-2014Perindustrian pada 28-12-2019

[2] Smith D M 1981 Industrial Location (New York: John Wiley \& Son)

[3] Dirdjojuwono R W 2004 Kawasan Industri Indonesia (Bogor: Pustaka Wira Usaha)

[4] Abdurachmat I, dan Enok M 1997 Geografi Ekonomi (Bandung: Jurusan Pendidikan Geografi FPIPS IKIP Bandung)

[5] Badan Pusat Statistik 2014 Klaten dalam Angka 2014 Diakses dari https://klatenkab.bps.go.id/publication/2014/12/01/ac9158539c71a9596bb110b6/klat en-dalam-angka-2014.html pada 28-12-2019

[6] Stone M 1974 Cross Validatiry Choice and Assement of Statistical Predictions Journal of the Royal Statistical Society Series B 36 111-33 Diakses dari https://www.jstor.org/stable/2984809?seq=1 pada 06-01-2020

[7] Djajadiningrat S T, dan Melia F 2004 Kawasan Industri Berwawasan Lingkungan (Bandung: Rekayasa Sains)

[8] Triyanto 2013 Peningkatan Daya Saing Tenun "Lurik" Tradisional Melalui Pemanfaatan Hak Kekayaan Intelektual JP 3 Diakses dari http://ip.feb.unsoed.ac.id/index.php/sca1/article/view/255 pada 28-12-2019

[9] Kotler P, dan Armstrong G 2008 Prinsip-Prinsip Pemasaran (Jakarta: Erlangga)

[10] Peraturan Menteri Perindustrian Republik Indonesia Nomor 35 Tahun 2010 tentang Pedoman Teknis Kawasan Industri Diakses dari https://peraturan.bkpm.go.id/jdih/userfiles/batang/permen deprin 35 2010.pdf pada 06-01-2020 